\title{
Jurnal Teknologi Pangan dan Hasil Pertanian
}

http://journals.usm.ac.id/index.php/jtphp

\section{Substitusi Wortel (Daucus carota L.) dan Tepung Mocaf (Modified Cassava Flour) Terhadap Sifat Fisikokimia Dan Organoleptik Mie Kering}

\author{
Nadian Ernaningtyas $^{1 \bowtie}$, Sri Budi Wahjuningsih ${ }^{2}$, Sri Haryati ${ }^{3}$ \\ ${ }^{1}$ Mahasiswa Jurusan Teknologi Hasil Pertanian. Fakultas Teknologi Pertanian, Universitas \\ Semarang \\ ${ }^{2,3}$ Staff Pengajar Jurusan Teknologi Hasil Pertanian, Fakultas Teknologi Pertanian, Universitas \\ Semarang \\ Jurusan Teknologi Hasil Pertanian, Fakultas Teknologi Pertanian, Universitas Semarang, \\ Indonesia
}

DOI: http://dx.doi.org/10.26623/jtphp.v13i1.1845.

\section{Info Artikel}

Sejarah Artikel:

Disubmit 27 Agustus 2020

Direvisi 11 September 2020

Disetujui 25 September 2020

Keywords:

Carrots; Mocaf; Dry Noodles

\begin{abstract}
Abstrak
Tujuan penelitian ini untuk mengetahui apakah substitusi wortel dan tepung mocaf berpengaruh terhadap sifat fisikokimia dan organoleptic mie kering. Penelitian dilakukan menggunakan Rancangan Acak Kelompok (RAK) 1 faktor menggunakan 5 perlakuan 4 ulangan. Pelakuan yang diterapkan adalah perbandingan wortel dan tepung mocaf pada P1 (0:40), P2 (10:30). P3 (20:20), P4 (30:10), P5 (0:40), terigu 60 g, air, CMC 2 g, dan garam 0,5 g. Data dianalisis dengan ANOVA. Dilanjutkan dengan Uji Duncan (DMRT) pada taraf $5 \%$. Penelitian ini menunjukkan pengaruh substitusi wortel dan tepung mocaf terhadap tensile strength, rehidrasi, kadar air, $\beta$-karoten, serat kasar, dan uji organoleptik meliputi uji hedonic warna, tekstur, rasa mie kering. Perlakuan terbaik adalah P4 dengan nilai daya putus $0,017050 \mathrm{Mpa}$, daya rehidrasi 1,120575 , kadar air $9,34475 \%$, $\beta$ karoten 5951,323925 $\mu . \mathrm{g} / 100 \mathrm{~g}$, serat kasar $1,05975 \%$, dan memiliki tingkat kerusaan warna 5,5 (suka-sangat suka), tekstur 5,2 (suka-sangat suka), dan rasa 6,4 (sangat sukaamat sangat suka).
\end{abstract}

\begin{abstract}
The purpose of this study was to determine whether the substitution of carrots and mocaf flour had an effect on the physicochemical and organoleptic properties of dry noodles. The study was conducted using a randomized block design (RBD) with 1 factor using 5 treatments and 4 replications. The treatment applied was the ratio of carrots and mocaf flour at P1 (0:40), P2 (10:30). P3 (20:20), P4 (30:10), P5 (0:40), $60 \mathrm{~g}$ flour, water, $2 \mathrm{~g} C M C$, and $0.5 \mathrm{~g}$ salt. Data were analyzed by ANOVA. Followed by the Duncan Test (DMRT) at the 5\% level. This study shows the effect of carrot substitution and mocaf flour on tensile strength, rehydration, moisture content, $\beta$ carotene, crude fiber, and organoleptic tests including hedonic test, color, texture, and taste of dry noodles. The best treatment was P4 with a breaking strength value of $0.017050 \mathrm{Mpa}$, rehydration power of 1.120575 , moisture content of $9.34475 \%$, $\beta$-carotene $5951.323925 \mu . \mathrm{g} / 100 \mathrm{~g}$, crude fiber $1.05975 \%$, and had a level of color degradation. 5.5 (like very much), texture 5.2 (like very much), and taste 6.4 (very much like very, very much).
\end{abstract}

\footnotetext{
Alamat Korespondensi: Nadian Ernaningtyas, Fakultas Teknologi Pertanian Universitas Semarang, J1 Soekarno-Hatta, Tlogosari Semarang E-mail: nadianernaningtyas76@gmail.com 


\section{PENDAHULUAN}

Mie merupakan salah satu makanan berbahan dasar tepung yang diminati banyak orang, khususnya masyarakat Indonesia. Mie dapat dengan mudah ditemukan dipasar atau swalayan. Mie yang beredar di masyarakat umumnya berbahan dasar terigu, yang mana di Indonesia masih belum bisa memproduksi gandum sebagai bahan baku pembuatan tepung terigu. Sehingga untuk memproduksi terigu diperlukan impor gandum. Hal ini dapat menyebabkan Indonesia harus terus menerus impor gandum yang dapat menyebabkan ketergantungan. Oleh karena diperlukan bahan lain pengganti terigu agar dapat mengurangi impor gandum.

Tepung Mocaf atau Mocaf adalah singkatan dari Modified Cassava Flour yang berarti singkong yang dimodifikasi. Secara definitive, MOCAL adalah produk tepung dari singkong atau ubi kayu yang diproses menggunakan prinsip memodifikasi sel singkong secara fermentasi, dimana BAL (Bakteri Asam Laktat) mendominasi selama fermentasi singkong ini (Subagio, 2008).

Penelitian sebelumnya yang dilakukan oleh Gumelar (2019) menghasilkan mie kering dengan substitusi tepung mocaf $40 \%$ dan tepung terigu $60 \%$ adalah perlakuan terbaik yang disukai panelis. Dari penelitian sebelumnya, mie mocaf yang dihasilkan cenderung berwarna pucat. Oleh karena itu diperlukan bahan lain yang dapat digunakan sebagai pewarna mie mocaf.

Wortel (Daucus carota L.) adalah tumbuhan jenis sayuran dengan umbi berwarna oranye atau jingga dengan tekstur keras. Wortel dapat dengan mudah ditemukan di Indonesia. Penggunaan wortel sebagai pewarna alami dirasa cocok karena wortel mengandung $\beta$-karoten yang memberi pigmen warna oranye. Selain itu, wortel memiliki kandungan vitamin A dan kaya akan $\beta$-karoten, sehingga selain untuk pewarna, wortel dapat digunakan untuk menambah kandungan gizi pada makanan. Dengan demikian, penelitian ini dilakukan untuk mengurangi penggunaan tepung terigu dengan menggunakan tepung mocaf dan penggunan wortel sebagai pewarna alami dan kandungan karotenoid pada wortel yang dapat berfungsi sebagai antioksidan.

\section{METODE}

Penelitian ini dilakukan pada Oktober 2019 sampai Juli 2020 di Techno Park Grobogan, Laboratorium Kimia,Laboratorium Rekayasa Pangan, dan Laboratorium Uji Indrawi Fakultas Teknologi Pertanian Universitas Semarang.

Alat yang digunakan untuk membuat mie kering yaitu mesin pembuat mie "Atlas Pasta Maker", pengukus mie,blender (Philips 2LHR2115),timbangan digital, cetakan mie, wadah, pisau, Loyang panic. Alat-alat yang digunakan untuk analisa yaitu oven "Memmert", tanur, cawan,botol timbang, timbangan analitik, texture analyzer merk Brookfield tipe CT-03.

Bahan yang digunakan untuk membuat mie kering yaitu tepung terigu protein tinggi merk kunci biru dan tepung mocaf yang diproduksi di Techno Park Grobogan, wortel, CMC yang diperoleh dari toko kimia, garam, dan air merk AQUA. Bahan yang digunakan untuk analisa yaitu Aquadest, $\mathrm{NaOH}, \mathrm{CuSO} 4$, dan bahan bahan lain.

\section{TAHAPAN PENELITIAN}

Proses pembuatan mie kering dengan substitusi wortel dan tepung mocaf diawali dengan pembuatan lumatan wortel terlebih dahulu. Wortel yang sudah dikupas lalu dipotong dadu $(1 \mathrm{~cm})$, kemudian dicuci lalu diblaching dengan cara dikukus selama 3- 5 menit. Proses ini bertujuan menghilangkan bau langu pada wortel, kemudian wortel dihaluskan menggunakan blender sampai halus. Kemudian disiapkan tepung mocaf dan air untuk dilakukan proses gelatinisasi dengan mencampur mocaf dan air (5:3) lalu dikukus selama \pm 30 menit. Disiapkan bahan untuk membuat mie. Proses pembuatan mie dengan substitusi wortel dan tepung mocaf dimulai dengan mencampur semua bahan, meliputi lumatan wortel, tepung mocaf, tepung terigu, air, CMC, garam sesuai 
perlakuan kemudian dipipihkan dengan mesin sheeter. Setelah adonan pipih kemudian dilakukan pembuatan untaian dengan slitter lalu dikukus selama 25 menit dengan suhu $100^{\circ} \mathrm{C}$. Mie yang sudah dikukus kemudian dikeringkan selama 8 jam dibawah sinar matahari. Mie kering dengan substitusi wortel dan tepung mocaf dikemas dan siap diuji.

\section{PENGOLAHAN DATA DAN ANALISIS DATA}

Daya Putus (Tensile Strength)

Pengujian tarik (tensile test) adalah pengujian mekanik secara statis dengan cara sampel ditarik dengan pembebanan pada kedua ujungnya dimana gaya tarik yang diberikan sebesar $\mathrm{P}$ (Newton). Dalam pengujiannya, bahan uji ditarik sampai putus.

\section{Daya Rehidrasi}

Pengukuran daya rehidrasi dilakukan dengan metode penimbangan. Daya Rehidrasi adalah kemampuan mie untuk menyerap air setelah gelatinisasi. Pengukuran dilakukan dengan menimbang $5 \mathrm{~g}$ mie mentah sebagai a g, kemudian direbus sampai tergelatinisasi sempurna ( \pm 4 menit). Setelah masak, kemudian ditiriskan dan ditimbang sebagai $\mathrm{b} g$.

$$
\text { Daya Rehidrasi (\%) }=((b-a) / a) \times 100 \%
$$

\section{Kadar Air (AOAC, 2007)}

Analisis kadar air dilakukan dengan metode oven. Prinsipnya dengan menguapkan molekul air bebas yang ada dalam sampel. Sampel ditimbang sampai didapat bobot konstan dengan asumsi semua air yang terkandung dalam sampel sudah diuapkan. Banyaknya air yang diuapkan merupakan selisih bobot sebelum dan sesudah pengeringan. Cawan yang akan digunakan dioven terlebih dahulu selama 30 menit pada suhu $100-105^{\circ} \mathrm{C}$. Cawan didinginkan dalam desikator untuk menghilangkan uap air dan ditimbang. Sampel ditimbang sebanyak $2 \mathrm{~g}$ dalam cawan yang sudah dikeringkan kemudian dioven pada suhu $100-105^{\circ} \mathrm{C}$ selama $5 \mathrm{jam}$. Sampel didinginkan dalam desikator selama 30 menit dan ditimbang. Tahap ini diulangi hingga dicapai bobot yang konstan. Penentuan kadar air dihitung dengan rumus sebagai berikut:

$$
\text { Kadar Air (\%) }=\frac{\mathrm{W} 1-\mathrm{w} 2}{\mathrm{w} 1} \times 100 \%
$$

\section{Keterangan :}

W1 : berat sampel sebelum dikeringkan

W2 :berat sampel setelah dikeringkan 


\section{Kadar $\beta$-karoten (Parwata et al., 2010)}

Masing-masing $4 \mu \mathrm{L}$ sampel ditotolkan pada plat. Penotolan dilakukan dengan menggunakan Linomat IV. Luas puncak kromatogram dibaca pada panjang gelombang maksimum dibawah TLC Scanner, diulang sebanyak tiga kali. Hasil yang diperoleh digunakan untuk menentukan kadar $\beta$ karoten dengan menggunakan persamaan garis regresliner $\mathrm{y}=\mathrm{bx}+\mathrm{a}$, dengan rumus :

$$
\begin{gathered}
\mathrm{b}=\frac{n \Sigma x y-\Sigma x \Sigma y}{n \Sigma x^{2}-(\Sigma x)^{2}} \\
\mathrm{a}=\frac{\Sigma y-b \Sigma x}{n}
\end{gathered}
$$

\section{Kadar Serat Kasar (Sudarmadji et al., 1989)}

Sebanyak $2 \mathrm{~g}$ sampel dimasukkan ke dalam labu erlenmeyer $500 \mathrm{ml}$ kemudian ditambahkan $200 \mathrm{ml} \mathrm{H} 2 \mathrm{SO} 4$ 0,255 $\mathrm{N}$ dan ditutup dengan pendingin balik. Dididihkan selama 30 menit dan kadang kala digoyang-goyangkan. Disaring suspensi dan residu yang tertinggal dalam erlenmeyer dicuci dengan aquadest mendidih melalui kertas saring sampai air cucian tidak bersifat asam (uji dengan kertas indikator $\mathrm{Ph}$ ). Residu diatas kertas saring dipindahkan kembali secara kuantitatif ke dalam erlenmeyer dengan menggunakan spatula. Sisanya dicuci dengan $\mathrm{NaOh} 0,313 \mathrm{~N}$ sebanyak $200 \mathrm{ml}$ sampai semua residu masuk kedalam erlenmeyer. Dididihkan dengan pendingin balik selama 30 menit. Disaring melalui kertas saring yang telah diketahui beratnya setelah dikeringkan, sambil dicuci berturut-turut dengan larutan $\mathrm{K} 2 \mathrm{SO} 4$ 10\% aquadest mendidih, dan alkohol masingmasing sebanyak $15 \mathrm{ml}$. Kertas saring beserta isinya dikeringkan pada suhu $105^{\circ} \mathrm{C}$ sampai berat konstan (1-2 jam). Didinginkan dalam desikator dan ditimbang dengan mengurangkan berat kertas saring yang digunakan. Kadar serat kasar dapat dihitung dengan rumus :

\section{Uji Organoleptik}

$$
\text { Kadar Serat Kasar }(\%)=\frac{\text { Berat } \text { kertas } \text { saring }(g)+\text { Berat } \text { kertas saring }(g)}{\text { Bobot sampel awal }(g)}
$$

Uji organoleptik yang digunakan yaitu tingkat kesukaan atau uji hedonik, panelis dimintatanggapan pribadinya tentang .Prinsip dari uji hedonik adalah berdasarkan penilaian panelis terhadap sifat organoleptik dengan penganalisaan tingkat kesan kesukaan (Kartika dkk.,1988).

\section{HASIL DAN PEMBAHASAN \\ Daya Putus (Tensile Strength)}

Substitusi wortel dan tepung mocaf pada mie kering memberikan pengaruh nyata $(p<0,05)$ terhadap daya putus mie kering masak. Uji Lanjut dengan Duncan's Multiple Range Test (DMRT) pada taraf $5 \%$ yang menyatakan bahwa terdapat perbedaan antar perlakuan dapat dilihat pada Gambar 1. Berdasarkan hasil analisa yang disajikan pada gambar, menunjukkan bahwa semakin tinggi penambahan wortel, maka semakin tinggi pula nilai tensile strength. Nilai tensile strength berhubungan dengan kandungan protein. Semakin rendah kandungan protein gluten pada mie, menyebabkan mie yang dihasilkan lembek dan mudah patah. Sehingga semakin tinggi penambahan tepung mocaf, nilai tensile strength semakin menurun. Umri et al., (2016) menyatakan Nilai tensile strength sangat berhubungan erat dengan kandungan protein. Semakin rendah kadar protein maka nilai tensile strength juga akan menurun. 
Jurnal Teknologi Pangan dan Hasil Pertanian 15 (2) (2020)

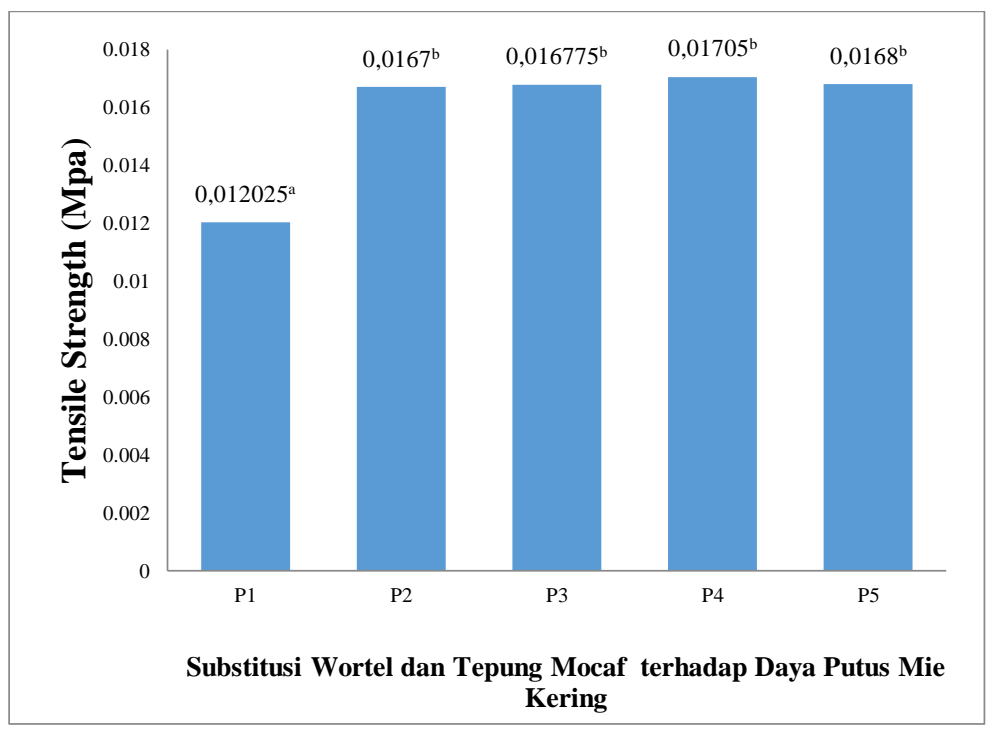

Gambar 1. Diagram Batang Tensil Strength Mie Kering Substitusi Wortel dan Tepung Mocaf

\section{Daya Rehidrasi}

Substitusi wortel dan tepung mocaf pada mie kering memberikan pengaruh nyata $(p<0,05)$ terhadap daya rehidrasi mie kering masak. Uji Lanjut dengan Duncan's Multiple Range Test (DMRT) pada taraf 5\% yang menyatakan bahwa terdapat perbedaan antar perlakuan dapat dilihat dapat dilihat pada Gambar 2. Semakin banyak substitusi tepung mocaf maka semakin tinggi daya rehidrasi. Ini dikarenakan pada tepung mocaf mengandung lebih banyak protein daripada wortel, yaitu sebesar $1 \%$ (maksimal) (Subagyo et. al, 2006). Sedangkan wortel hanya mengandung $0,9 \%$ (USDA, 2007). De Man (1997) pada Trisnawati (2015) menyatakan bahwa semakin tinggi protein, semakin tinggi pula daya serapnya. Trisnawati (2015) menyatakan penambahan konsentrat protein akan meningkatkan daya hidrasi.

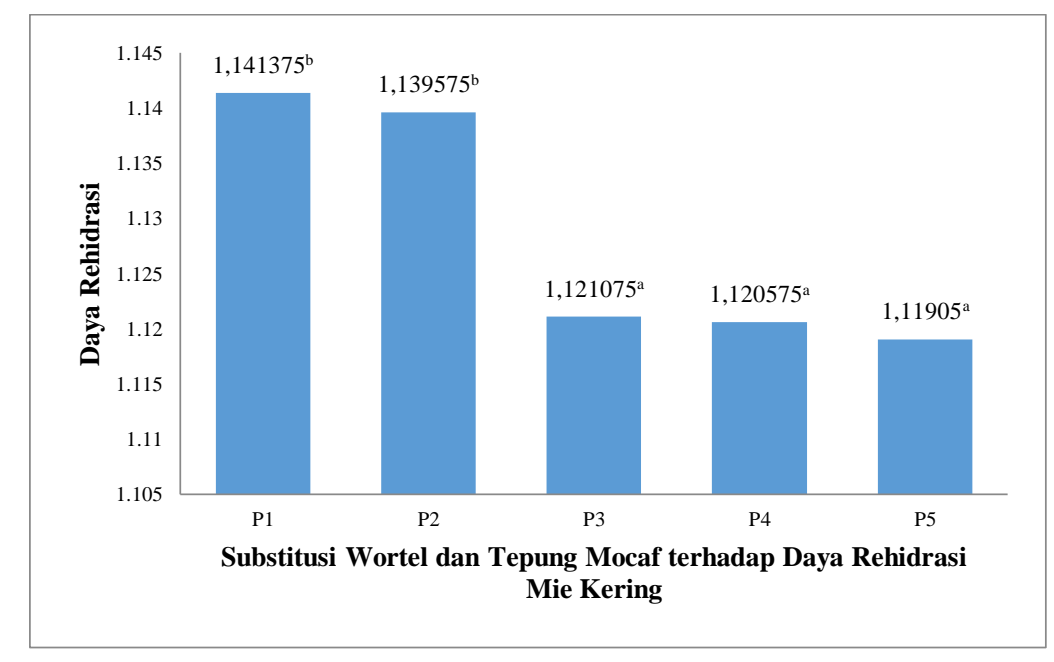

Gambar 2. Diagram Batang Daya Rehidrasi Mie Kering Substitusi Wortel dan Tepung Mocaf 


\section{Kadar Air}

Substitusi wortel dan tepung mocaf pada mie kering memberikan pengaruh nyata $(p<0,05)$ terhadap kadar air mie kering. Uji Lanjut dengan Duncan's Multiple Range Test (DMRT) pada taraf 5\% yang menyatakan bahwa terdapat perbedaan antar perlakuan dapat dilihat pada Gambar 3. Kadar air mie kering dengan substitusi wortel dan tepung mocaf yang tersaji pada gambar. Gambar menunjukkan semakin sedikit tepung mocaf dan semakin banyak wortel, maka kadar air semakin tinggi. Ini dikarenakan pada tepung mocaf mengandung kadar air maksimal 13\% (USDA, 2007), dan wortel sebesar 88,29\% (SNI 7622-2011). Hal ini sesuai dengan penelitian Hurabarat (2017) yang menyatakan bahwa semakin banyak wortel yang ditambahkan, maka kadar air ledok akan meningkat. Ini disebabkan karena wortel memiliki kandungan air yang tinggi, sehingga mempengaruhi kadar air ledok.

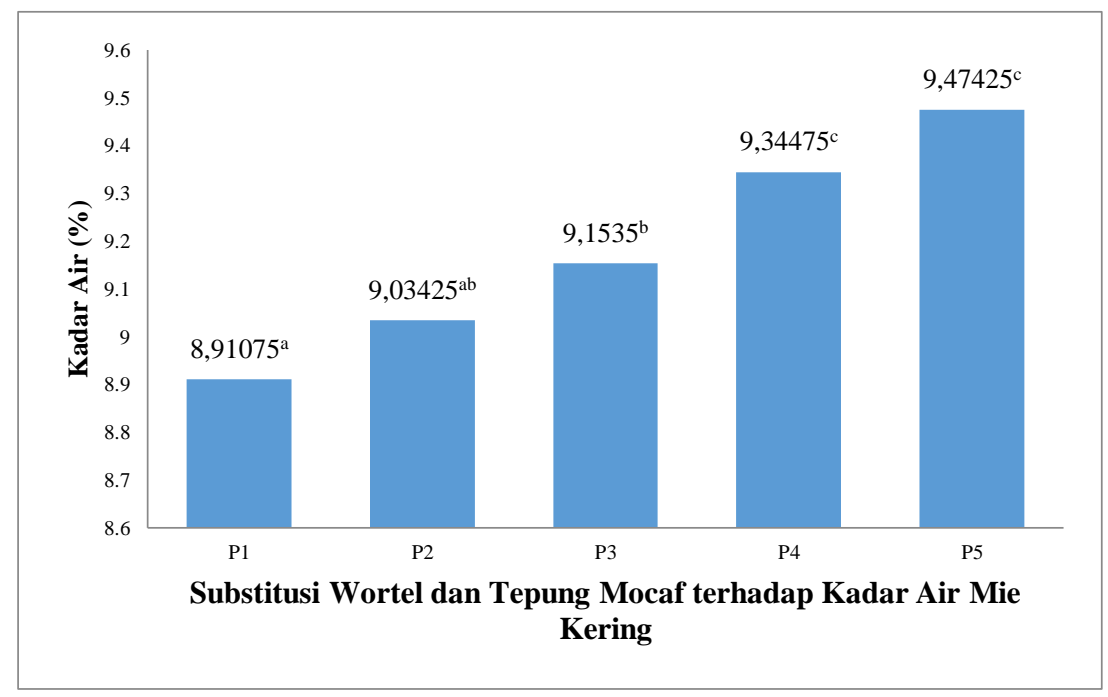

Gambar 3. Diagram Batang Kadar Air Mie Kering Substitusi Wortel dan Tepung Mocaf

\section{Kadar $\beta$-Karoten}

Substitusi wortel dan tepung mocaf pada mie kering memberikan pengaruh nyata $(\mathrm{p}<0,05)$ terhadap $\beta$-karoten mie kering masak. Uji Lanjut dengan Duncan's Multiple Range Test (DMRT) pada taraf $5 \%$ yang menyatakan bahwa terdapat perbedaan antar perlakuan dapat dilihat pada Gambar 4. Dari Gambar 4 menunjukkan kadar $\beta$-karoten dari P1 sampai P5 mengalami peningkatan. Hal ini disebabkan oleh nilai $\beta$-karoten pada wortel sebesar $8285 \mathrm{Mcg} / 100 \mathrm{~g}$ (USDA, 2016). Sehingga semakin tinggi penambahan lumatan wortel pada substitusi mie kering, maka semakin tinggi kadar $\beta$-karoten yang dihasilkan. Hutabarat et al., (2017) menyatakan peningkatan kadar $\beta$-karoten disebabkan karena wortel yang ditambahkan merupakan sayuran yang memiliki betakaroten tinggi. Semakin banyak jumlah wortel yang ditambahkan, maka $\beta$-karoten akan semakin meningkat. 
Jurnal Teknologi Pangan dan Hasil Pertanian 15 (2) (2020)

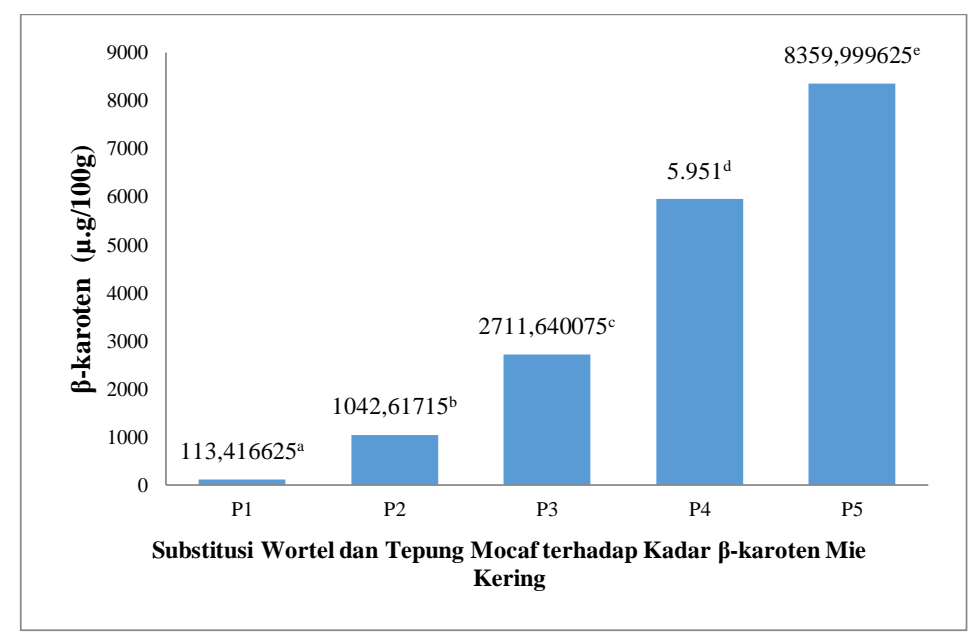

Gambar 4. Diagram Batang $\beta$-karoten Mie Kering Substitusi Wortel dan Tepung Mocaf

\section{Serat Kasar}

Substitusi wortel dan tepung mocaf pada mie kering memberikan pengaruh nyata $(p<0,05)$ terhadap daya serat kasar mie kering. Uji Lanjut dengan Duncan's Multiple Range Test (DMRT) pada taraf $5 \%$ yang menyatakan bahwa terdapat perbedaan antar perlakuan dapat dilihat pada Gambar 5. Semakin banyak subtitusi wortel yang ditambahkan maka kadar serat pada mie kering semakin tinggi sedangkan semakin tinggi subtitusi tepung mocaf kadar serat pada mie kering semakin rendah. Hal ini disebabkan karena kandungan serat pada wortel 2,8 \% (USDA, 2007) sedsangkan Mocaf 1,9\% (Codex Stan 1989 dalam Subagyo et al., ). Pernyataan ini sesuai dengan penelitian Lestario, dkk yang menyatakan semakin besar penambahan tepung wortel, makin meningkat pula kadar serat kasar mie yang dihasilkan.

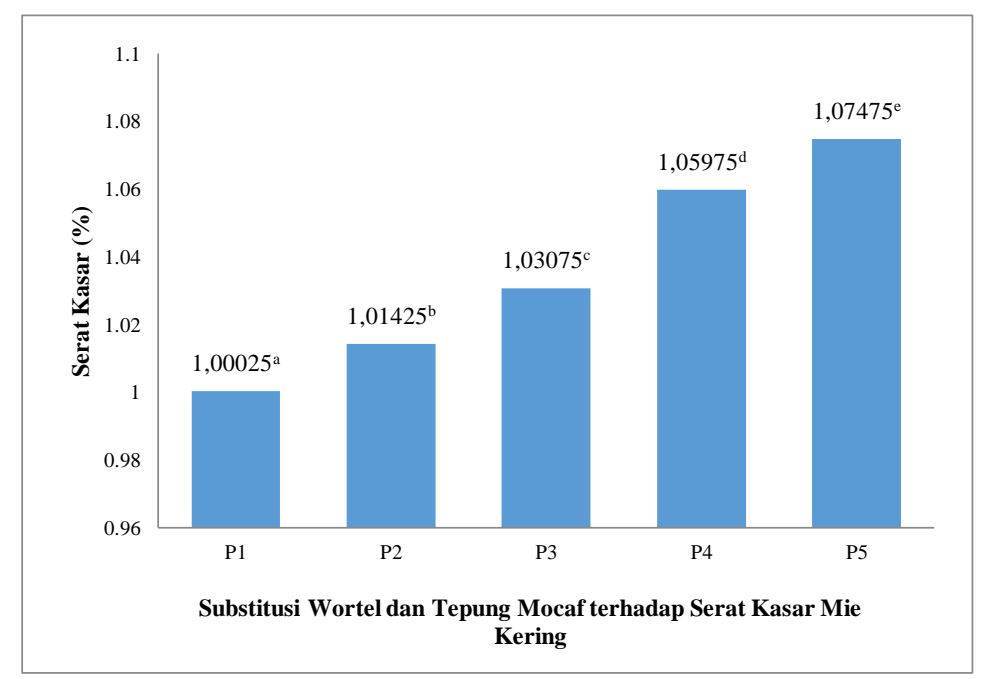

Gambar 5. Diagram Batang Serat Kasar Mie Kering Substitusi Wortel dan Tepung Mocaf 


\section{Uji Hedonik Warna}

Substitusi wortel dan tepung mocaf pada mie kering memberikan pengaruh nyata $(p<0,05)$ terhadap uji organoleptic warna mie kering masak. Uji Lanjut dengan Duncan's Multiple Range Test (DMRT) pada taraf 5\% yang menyatakan bahwa terdapat perbedaan antar perlakuan dapat dilihat pada Gambar 6.

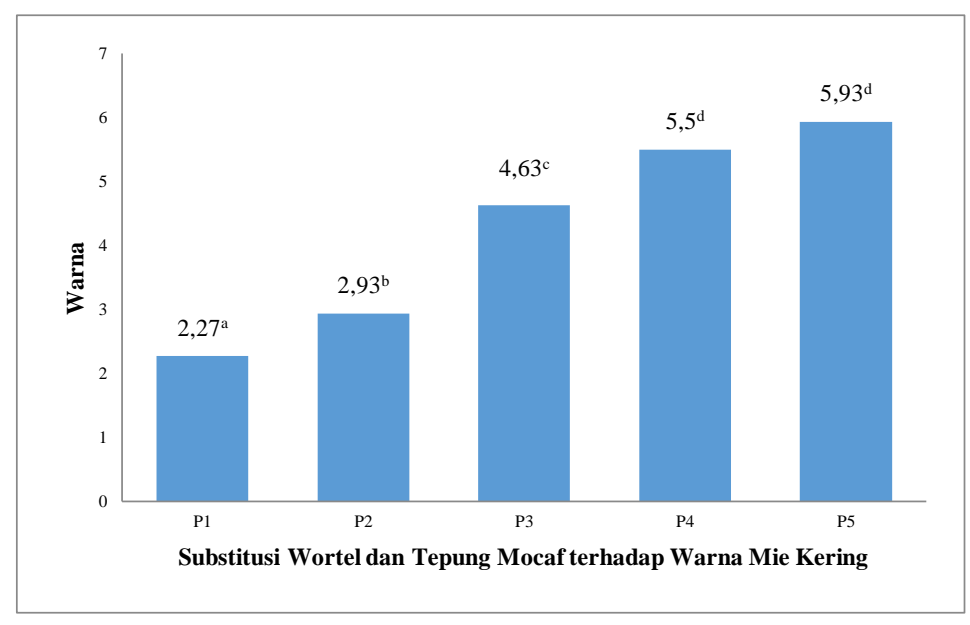

Gambar 6. Diagram Batang Warna Mie Kering Substitusi Wortel dan Tepung Mocaf

Hasil analisa organoleptic warna yang tertinggi pada P5. Meningkatnya parameter warna yang disukai panelis dikarenakan adanya jumlah substitusi wortel yang tinggi, maka warna yang dihasilkan cerah dan menarik perhatian. Warna yang dihasilkan dari senyawa karatenoid pada wortel yang menghasilkan warna kuning sampai oren. Hutabarat, dkk (2017) menyatakan bahwa semakin banyak jumlah wortel yang ditambahkan, maka semakin meningkat nilai sensorinya.

\section{Uji Hedonic Tekstur}

Substitusi wortel dan tepung mocaf pada mie kering memberikan pengaruh nyata $(p<0,05)$ terhadap uji organoleptic tekstur mie kering masak. Uji Lanjut dengan Duncan's Multiple Range Test (DMRT) pada taraf 5\% yang menyatakan bahwa terdapat perbedaan antar perlakuan dapat dilihat pada Gambar 7. Pada tingkat kesukaan panelis, yang paling disukai pada perlakuan P3 dikarenakan panelis menyukai tekstur yang tidak mudah putus dan tidak terlalu keras. 


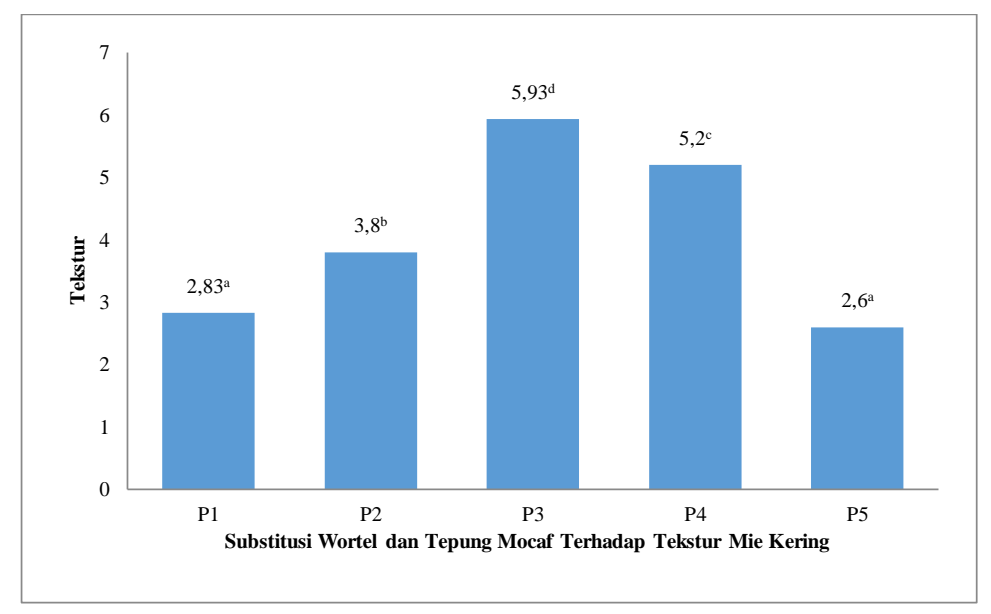

Gambar 7. Diagram Batang Tekstur Mie Kering Substitusi Wortel dan Tepung Mocaf

\section{Uji Hedonic Rasa}

Substitusi wortel dan tepung mocaf pada mie kering memberikan pengaruh nyata $(p<0,05)$ terhadap uji organoleptic rasa mie kering masak. Uji Lanjut dengan Duncan's Multiple Range Test (DMRT) pada taraf 5\% dapat dilihat pada Gambar 8. P4 memiliki nilai kesukaan sangat suka - amat sangat suka, yang disebabkan mie memiliki rasa manis yang berasal dari wortel dan dengan sedikit campuran tepung mocaf. Faridah dan Kasmita (2006) menyatakan bahwa wortel memberi rasa manis, sehingga mempengaruhi rasa mie yang dihasilkan

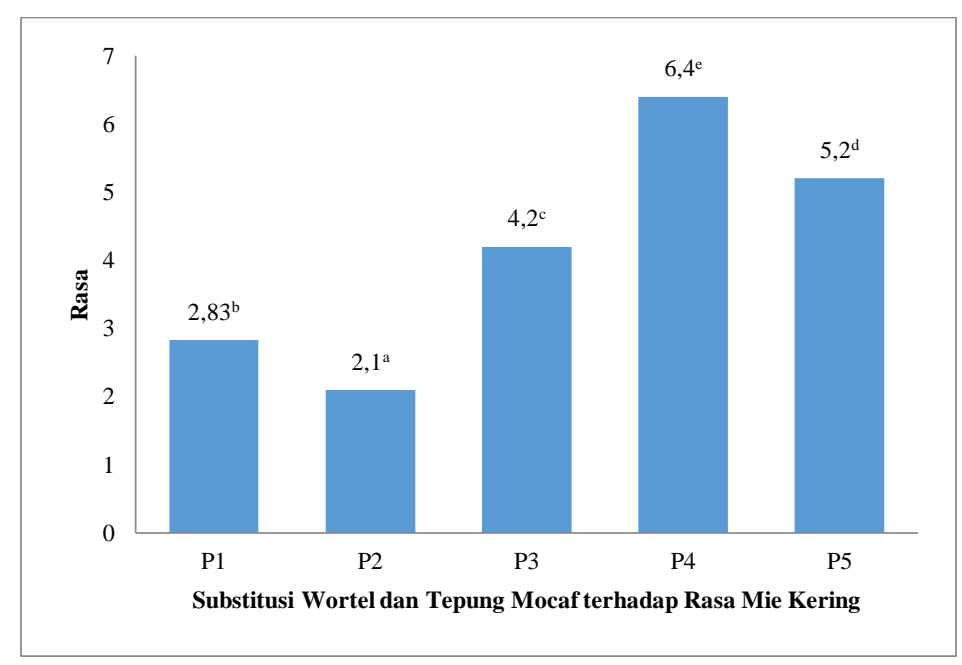

Gambar 8. Diagram Batang Rasa Mie Kering Substitusi Wortel dan Tepung Mocaf 


\section{SIMPULAN}

Substitusi wortel dan tepung mocaf terhadap sifat fisikokimia dan organoleptik mie kering berpengaruh nyata $(p<0,05)$ terhadap daya putus (tensile strengty), daya rehidrasi, kadar air, kadar $\beta$-karoten, serat kasar, warna, tekstur, dan rasa.

Perlakuan terbaik pada P4 dengan substitusi wortel $30 \mathrm{~g}$ dan mocaf $10 \mathrm{~g}$. Nilai daya putus

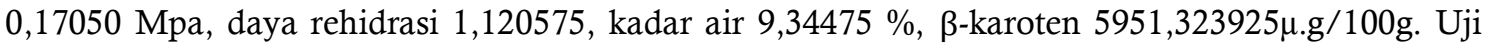
organoleptic warna 5,5 (suka-sangat suk), tekstur 5,2 (suka-sangat suka), dan rasa 6,4 (sangat sukaamat sangat suka)

\section{DAFTAR PUSTAKA}

AOAC. 2007.Official Method of Analysis of The Association of Official Analytical Chemist.Association of Official Analytical ChemistWashington, D.C.

Hutabarat, Fransen Kennedy., Yusa, Ni Made., Wiadnyani, A.A.I Sri. 2017. Pengaruh Penambahan Wortel (Daucus carota L.) Terhadap Karakteristik Ledok.Universitas Udayana.

Lestario, Lydia Ninan., Indrati, Niken., Dewi, Lusiawati. (Tanpa Tahun). Fortifikasi Mie dengan Tepung Wortel. Universitas Kristen Satya Wacana.

Parwata, O.A., Ratnayani K., Listya, A. 2010. Aktivitas Antiradikal Bebas Serta Kadar Beta Karoten Pada Madu Randu (Ceiba pentandra) dan Madu Kelengkeng (Nephelium longata 1.) jurnal Kimia 4:54-62

Sudarmadji, S., B. Haryono, dan Suhardi. 1984. Prosedur Analisis Untuk Bahan Makanan dan Pertanian. Edisi Ketiga. Yogyakarta: Penerbit Liberty.

Subagio, A. 2006. Industrialisasi Modified Cassaava Flour (MOCAF) Sebagai Bahan Baku Industri Pangan untuk Menunjang Diversifikasi Pangan Pokok Nasional. Tidak Diterbitkan. Fakultas Teknologi Pertanian, Universitas Jember. Jember

Trisnawati, Merina Ling., Nisa, Fithri Choirun. 2015. Pengaruh Penambahan Konsentrat Protein Daun Kelor Dan Karagenan Terhadap Kualitas Mie Kering Tersubstitusi Mocaf. Jurnal Pangan dan Agroindustri Vol. 3 No 1 p.237-247.

Umri, Arsyi Wintaha., Nurrahman., H, Wikanasari. 2016. Kadar Protein, Tensile Strength, dan Sifat Organoleptik Mie Basah dengan Substitusi Tepung Mocaf. Universitas Muhammadiyah Semarang. 